\title{
VERDADE E MORALIDADE EM ALASDAIR MACINTYRE'
}

\author{
Truth and morality in Alasdair MacIntyre
}

Helder Buenos Aires de Carvallho

UFPI

Sumário: O artigo discute a relação entre verdade e moralidade na ética das virtudes de Alasdair MacIntyre, apontando para a tensão entre o realismo metafísico-teológico pressuposto em sua virada tomista a partir de Three Rival Versions of Moral Enquiry, e a matriz, a nosso ver, claramente hermenêutico-pragmática de seu modelo da racionalidade das tradições morais de pesquisa racional, explicitado anteriormente em $D e p o i s ~ d a$ Virtude em Justiça de Quem? Qual Racionalidade?

Palavras-Chaves Verdade, Moralidade, MacIntyre, Ética das Virtudes, Realismo

Summary: The paper discusses the relationship between truth and morality in Alasdair Macintyre's virtue ethics, by pointing to the question of theoretical tension between the Metaphysical-Theological realism assumed in his Thomist turn from Three Rival Versions of Moral Enquiry on his later works, and the hermeneutical-pragmatic background of the model of the rationality of moral inquiry traditions earlier proposed in After Virtue and in Whose Justice? Which Rationality?

Keywords: Truth, Morality, MacIntyre, Virtue Ethics, Realism, Hermeneutics

I

Como aponta Marcondes (2014), a verdade é um artefato essencial da linguagem humana em sua interação com o mundo e os outros humanos: "é um conceito-chave não só para a Filosofia, mas para nosso pensamento, para nossa cultura de modo geral" (p.11). No âmbito moral é valorizada como um bem na forma de honestidade, sinceridade e transparência na relação com os outros, além de carregar a pretensão de os juízos morais possuírem validade para além da simples subjetividade dos agentes; no âmbito epistemológico é valorizada como conhecimento da realidade, a propriedade de representação ou do dizer do que seja o mundo como ele é. Enfim, possui um valor prático e teórico inestimável para o funcionamento da vida social e da civilização humana, sem o qual esta correria o risco de se dissolver.

E mesmo quando é posta como algo a ser desconsiderada, que não teria nenhum valor na interpretação do que o mundo é, tal como o fazem os céticos, ou mesmo do que é certo a se fazer na relação com os outros humanos, tal como fazem certos pós-modernistas de faceta relativista, termina por ser um pressuposto ineludível de ambas as perspectivas. Frankfurt (2007) observa que

"mesmo os que professam negar a validade ou a realidade objetiva da distinção verdadeiro/falso continuam a sustentar sem nenhuin constrangimento aparente que tal negativa é uma posição verdadeiramente endossada por eles. A asserção de que rejeitam a distinção entre verdadeiro e falso é, insistem eles, uma asserção incondicionalmente verdadeira, e não uma asserção falsa, sobre suas crenças" (p.15).

\footnotetext{
${ }^{1}$ Artigo escrito originalmente no âmbito de projeto com Bolsa de Produtividade/UFPI-2016/2017. Modificado posteriormente no âmbito de parte do estágio pós-doutoral desenvolvido na UFMG com bolsa CNPq-2017/2018. 
Nesse sentido, cometeriam o que Apel (2000) chamou de "contradição performativa", na medida em que o próprio ato de negar a verdade a pressupõe simultaneamente como uma condição necessária, intrínseca, no ato linguístico para garantia de seu sentido e validade e, por conseguinte, da interação humana não manipuladora pressuposta na comunicação.

Em seu livro sobre as novas teorias da verdade, Wright \& $\operatorname{P}$ Pedersen $(2010$, p.1) assinalam que a verdade permanece um objeto inabalável de estudo em todos os níveis de investigação dentro da fillosofia e fora dela, tanto no contexto acadêmico quanto no âmbito popular. $\mathbb{E}$ a grande quantidade de trabalhos nessa área nos últimos 20 anos, ${ }^{2}$ que estabeleceu a agenda dos debates fillosóficos sobre a verdade, mostra que muitas das questões, problemas e soluções têm se concretizado e, com isso, muitos desses debates se tornaram firmemente estabelecidos. Mas Kirkham (1995, p.1) sustenta que, paradoxalmente a essa profusão de trabalhos, uma revisão dos escritos sobre a verdade vai nos mostrar que há muito pouco acordo estabelecido sobre o que é exatamente o problema filosófico da verdade! $\mathrm{E}$ muitos poucos filósofos estão conscientes de que os filósofos de quem eles discordam no debate podem ter tido uma concepção diferente do problema filosófico da verdade ou mesmo acabam não deixando claro também qual é a sua própria concepção do problema ao criticar estes últimos.

O panorama geral de discussões em torno da verdade é, como descreve Blackburn (2006), confuso e retorcido, pouco afeito a nos oferecer alguma ajuda substantiva:

"Palaviras como 'relativismo" e 'pós-modernismo' indicam a cultura resuiltante, em que 'qualquer coisa serve' e embora seja isto mesmo um objeto de suspeita para os leigos inocentes, é pouco provável que eles as compreendan bem o suificiente para que se oponham de modo eficaz" (p.6).

Acrescenta aindla que a profusão de "ismos" que se apresenta nesse cenário é, na verdade, um conflito sobre "a concepção que temos de nós mesmos e do nosso mundo, sobre o significado do que dizemos e mais ainda sobre o significado de nossas atividades e de nossas vidas" (id., p.14). Falar sobre a verdade, dessa forma, não é apenas um problema epistêmico ou semântico, mas envolve formas de viver e de agir", não sendo à toa o fato de as pessoas se mobilizarem em torno dela e fazerem coisas significativas, por vezes inimagináveis e absurdas, em seu nome.

O problema filosófico da verdade é, assim, não apenas um problema epistemológico, sobre a sustentação e/ou superioridade de algumas crenças sobre outras, mas também um problema prático, que mergulha no âmbito moral - não apenas no sentido estabelecido por Williams (2002), ao discutir sobre as virtudes de falar a verdade, tais como a sinceridade e a precisão. Como observou Blackburn (2006),

Quando as pessoas se preocupam com uma "crise da verdade", nas humanidades por exemplo, a princípio elas não estão preocupadas com a sinceridade e ansioso zelo por parte daqueles que pertencem a determinado campo. Elas se preocupam com a possibilidade de que, embora sejamos sinceros e zelosos, estejamos encurralados por visões parcialmente, perspectivamente ou inequivocamente ilusórias e fictícias, com pouca ou nenhuma chance de perceber nosso apuro ( $p_{\text {.17 }}$ 18).

O conflito aparentemente insolúvel entre os que teorizam sobre a natureza da verdade abre espaço significativo para a ideia de que nossas histórias sobre o mundo e nós mesmos sejam transitórias, contingentes, desembocando em leituras e compreensões da verdade como um objetivo que nunca vai ser alcançado, produzindo a sensação e a atitude perversa de que, ao final das contas, ela não é tão importante ou valiosa, funcionando como instrumento de dominação ou manipulação - já nos alertava Nietzsche

${ }^{2}$ Ver Kirkham (1995), Lynch (2001, 2009), Engel (2002), Soames (1999), Schmitt (2003), Statman (1997) e Mosteller (2014) para uma visão mais ampliada dessa discussão. 
sobre isso, quando a chamava de um batallhão móvel de metáforas e metonímias. Assim, uma tarefa da filosofia é avançar nessa discussão para nos situarmos melhor diante desse aparente estado persistente de guerra intelectual e prática sobre a verdade, especialmente se considerarmos o debate moral e político hodierno, marcado pela globalização, integração e interrelação de culturas diferenciadas, no qual visões diferentes sobre a verdade, a racionalidade e a ética se (des)articulam - a ponto de se ter caracterizado nosso tempo como a época da pós-verdade, dos fatos alternativos! $!^{3}$

No âmbito da reflexão ética ocidental, muito especialmente no contexto contemporâneo, essa importância da verdade tem encontrado dificuldades significativas em ter o seu lugar reconhecido integralmente em se tratando da validade e objetividade dos juízos morais, especialmente pela natureza prática e não apenas teórica destes. Teorias metaéticas de matriz analítico-linguística, principalmente, tem teorizado o esvaziamento dos juízos morais como portadores de conteúdos objetivos, ou seja, como não sujeitos à verdade, reverberando a velha questão humeana da suposta separação ineludível entre fato e valor, além de acentuar o caráter linguístico da reflexão em torno da verdade dos proferimentos morais como estes provendo apenas expressão de sentimentos e preferências, apontando para um não-cognitivismo. Inicialmente designadas como versões do emotivismo, tais teorias são agora afirmadas como formas de expressivismo. ${ }^{4}$

Essa tematização da veridicidade dos juízos e qualidades morais tem sído realizada no âmbito da Metaética por meio das questões em torno da diferenciação entre fato e valor, entre o que supostamente envolveria apenas proposições descritivas, de caráter factual, daquilo que é, e proposições normativas, de caráter prático, guiadores da ação, daquilo que não é fato, mas deve ser. ${ }^{5}$ Toda a agudeza do problema ético se manifesta precisamente no fato de que um juízo moral não é uma simples descrição do mundo, de um dizer sobre como este é em determinado momento ou circunstância, mas pela pretensão de modificá-lo, de não deixá-lo simplesmente da forma como está, privilegiando, assim, a forma de um dever ser. Um juízo moral incorpoora uma avaliação de determinadas formas de ser no mundo, ao mesmo tempo que pressupõe ou usa elementos descritivos-objetivos sobre o ser do mundo nessa mesma avaliação.

O filósofo escocês, radicado nos Estados Unidos, Alasdair MacIntyre (1929-) tem se inserido nesse debate ético não apenas criticando as teorias metaéticas, vigentes mais fortemente no mundo anglo-saxão muito especialmente na metade do século XX, de se recusarem ao debate normativo e se refugiarem exclusivamente em uma análise lógicolinguística dos enunciados morais; mas também afirmando uma perspectiva filosóficomoral na qual as dimensões metaéticas e normativas não estejam isoladas entre si, separadas como se houvesse um muro insuperável entre fato e valor, ser e dever ser, ${ }^{6}$ bem como apontando continuamente o lugar que a verdade ocupa no contexto da racionalidade moral. Como apontou Darwall et alii (2013), mesmo esse debate entre as metaéticas de matrizes analíticas se modificou substantivamente no final do século XX na direção de visadas mais complexas, nas quais o elemento pragmático e social tem se incorporado na tematização da natureza dos juízos morais, não se mantendo exclusivamente na referência não cognitivista ou expressivista. Rouard (2010) também acentua que MacIntyre sempre tematizou a verdade, vinculando-a à dimensão histórica e experiencial, ainda que não possua propriamente, rigorosamente falando, uma teoria da verdade.

A forte retomada da ética das virtudes tem sido um evento intelectual importante na discussão ética contemporânea, especialmente pelos esforços de recuperação da ética teleológica de Aristóteles e outros pensadores em contextos diferenciados daqueles das

\footnotetext{
${ }^{3}$ A Oxford Dictionaries escolheu "pós-verdade" como a palavira do ano em 2016, definindo-a como um substantivo "que se relaciona ou denota circunstâncias nas quais fatos objetivos têm menos influência em moldar a opinião pública do que apelos à emoção e a crenças pessoais". Ver também Alex Grijelmo, "A arte de manipular mulltidões". El Páss. Seção Opinião. Publicado em 22.08.2017. Acesso em 30.05.2018, pelo link:

https:/brasil_elpais.com/brasil/2017/08/22/opinion/1503395946_889112.html

${ }^{4}$ Para uma visão mais ampla do expressivismo, ver: Schroeder (2010).

${ }^{5}$ Sobre a discussão contemporânea em Metaética, ver Darwall et alii (2013) e Miller (2003).

${ }^{6}$ Sobre o colapso dessa dicotomia, ver Putnam (2002).
} 
sociedades gregas e medievais, ${ }^{7}$ buscando alternativas aos problemas de insuficiência ainda persistentes nos paradigmas utilitarista e kantiano, além de seus desdobramentos. Esse revival (revivescência) das virtudes como centro da reflexão ética ${ }^{8}$ também não tem sido realizado em formas unitárias e contínuas, mas múltiplas e, por conseguinte, também reproduzindo a dificuldade de convergência existente nos demais paradigmas éticos.

Mas o que esse crescimento da ética das virtudes no final do século XX e começo do XXI revela é o reconhecimento de que a moralidade não pode mais ser pensada a partir de horizontes teóricos que não levem seriamente em consideração o papel do caráter do agente na avaliação e na efetivação dos cursos de ação possíveis que se põem diante dele(a); e não apenas um papel secundário, coadjuvante, mas de vetor principal e um constituidor significativo do próprio campo da moralidade enquanto práxis modulada por esse caráter.

Esse foco sobre as virtudes pode ser visto também como, em parte, uma das consequências da guinada pragmática na filosofia contemporânea ${ }^{9}$ na esteira das reflexões de Wittgenstein, com o seu Investigações Filosóficas, ${ }^{10}$ e dos filósofos da linguagem comum (Searle, Austin, dentre outros), que puseram as práticas linguísticas e sociais no centro do trabalho filosófico, de modo que aquilo que os agentes fazem e como eles se constituem como tal em seu agir, o seu modo de ser ou caráter, se tornassem elementos constitutivos da reflexão moral e filosófica - inclusive situando a linguagem mesma como uma prática social. Essa guinada para as práticas sociais ${ }^{11}$ tem também um outro componente com a presença importante do paradigma hermenêutico no cenário filosófico, ao colocar o problema da interpretação como um componente ontológico do contexto do agente que pensa, compreende e age historicamente, situando a verdade não mais apenas no contexto do método científico. ${ }^{12}$ Também está associada à herança marxiana das práticas produtivas materiais como elemento constituidor do homem e sua práxis histórica como um dos eixos a partir dos quais se deve pensar o que é o humano, seu bem próprio e a verdade mesma. ${ }^{13}$

\section{II}

Apesar das imagens do fim da filosofia ${ }^{14}$ e da emergência da tecnologia como o principal vetor definidor do modo de ser dos humanos nos últimos cinquenta anos, ${ }^{15} \mathrm{a}$ filosofia moral tem ocupado um lugar central nas discussões filosóficas correntes, como mostra o fato de que as perspectivas ético-morais se multiplicaram em um mundo póspositivista no qual a reflexão filosófica continua inabalada. A marca da ética se apresenta em todas as esferas da cultura, expressando-se na presença das linguagens éticas em todos os níveis da comunicação social, passando pela ciência, política, religião, práticas profissionais, leis, meio ambiente, medicina, tecnologia, informação, etc. E mesmo em um contexto de multiplicidade das visões sobre a verdade, esta continua sendo uma constitutiva significante das linguagens morais, que têm se ampliado na vida das culturas contemporâneas, especialmente as ocidentais, ao incorporar novos entes na esfera do mundo moral.

MacIntyre tem tido um papel importante, especialmente no universo anglo-saxão, nesse cenário filosófico desde o início dos anos 80, a partir de seu After Virtue (1981), ao se colocar como um dos principais representantes da chamada ética das virtudes. Nessa obra, ele defendeu vigorosamente a retomada da ética aristotélica das virtudes como saída para a crise moral que se sucedeu na modernidade pós-iluminista, sendo um dos

\footnotetext{
${ }^{7}$ Sobre isso, ver o conjunto de artigos publicados em Russell (2013); ver também Hobuss (2001), Carvalho (2011), van Hooft (2006), Darwall (2003), Statman (2014) e Crisp \& Slote (1997).

${ }^{8}$ Esse foco sobre a virtude tem se dado não apenas no âmbito da teoria moral, mas também na epistemologia. Ver Snow (2010); Zagzebski (1996); Fairweather \& Zagzebski (2001); Sosa (2009); Fairweather (2014).

${ }^{9}$ Sobre a virada pragmática na filosofia contemporânea ver Oliveira (1997).

${ }^{10}$ Ver Wittgenstein (1991).

${ }^{11}$ Ver Schatzki, T. R。; Knorr-Cetina, $K_{\circ}$, von Savigny, E。 (1985) e também Sterba (1985).

12 Ver fundamentalmente Gadamer (2004).

${ }^{13}$ Ver Oliveira (1995).

${ }^{14}$ Ver Vaz (1991, 1995), Rasmussen (1990) e Baynes, Bohman \& McCarthy (1987).

${ }^{15}$ Ver Jonas (1984), Carvalho (2011), Thde (1993) e Bruno (2003).
} 
responsáveis pela retomada das questões éticas substanciais no debate filosófico contemporâneo. Para MacIntyre, conforme afirmei em outro lugar (2013), a ética não apenas implica o exercício das virtudes, mas também de normas e regras, uma vez que estas são um elemento essencial para a aquisição de uma adequada concepção de bem. Recorrendo a uma concepção de normatividade internalista, MacIntyre busca articular uma teoria moral abrangente, capaz de incorporar de forma equilibrada as noções de dever e bem, sem cair num universalismo abstrato e descontextualizado ou num relativismo corrosivo, posturas tão em voga em boa parte das teorias morais contemporâneas. A teoria moral de MacIntyre tenta, portanto, garantir um mínimo de objetividade aos preceitos morais e ao papel da filosofia moral na dimensão normativa, sem abrir mão da historicidade e contingência que lhe são inerentes, mas também sem cair no relativismo moral ou na negação a priori do caráter racional das normas morais.

Em consequência do sucesso de After Virtue, seu trabalho tem sido interpretado majoritariamente a partir desse referencial aristotélico e, mais recentemente, por conta de sua produção nas últimas décadas nessa área, referenciado a Tomás de Aquino e à filosofia católica e, por conseguinte, o foco sobre o realismo metafísico que lhes são associados. Entretanto, essa apropriação que MacIntyre tem feito da filosofia de Tomás de Aquino não tem tido a mesma receptividade por parte de autores tomistas - ver George (1989), Coleman (1994) e Haldane (1994) - bem como não tem recebido uma atenção apropriada por grande parte de intérpretes do próprio MacIntyre - ver Knight (1999, 2007), Figueiredo (1994), Carvalho (1999, 2013), Díaz (2001), Gannon (1989), Lecaldano (1994), Matteini (1995), Carsillo (2000), Maddalena (2000), Vieira (2002) e Fuller (1998). Essa apropriação tem sido interpretadla seja como uma defesa pós-moderna do tomismo - ver Hibbs (1991, 1993) e Nancey Murphy $(1998,1995)$ - seja como uma interpretação equivocada do pensamento de Tomás de Aquino (George, 1989; Coleman, 1994; Abbà, 1989). Mas no mais das vezes é vista como não problemática, não recebendo uma análise devida, mantendo-se as críticas em outros pontos da sua teorização, feitas também frequentemente do ponto de vista do próprio tomismo. ${ }^{16}$

Como a trajetória filosófica de MacIntyre é mais diversificada que essa caracterização aristotélico-tomista deixa entrever, pois foi constituída sempre no embate com as filosofias do seu tempo histórico, seu pensamento tem origens variadas e é fruto de uma reflexão filosófica aberta e rica em suas apropriações teóricas ${ }^{17}$, nossa discussão busca se situar inicialmente para além dessa dicotomia e sustentar que essa apropriação, para poder fazer sentido adequado e mais amplo, não é uma simples defesa do Tomismo, mas uma tentativa de levar adiante uma tradição moral de pesquisa racional da qual o

\footnotetext{
${ }^{16}$ Essa perspectiva muito crítica à Macintyre, entretanto, tem se modificado nos últimos anos, passando a ter nosso filósofo uma leitura mais favorável. Para uma visão ampliada, ver Leonardi (2015). Ver também Gonçalves (2017a).

${ }^{17}$ O fato de MacIntyre ter tido uma trajetória intelectual bastante movimentada, na qual ocorreram diversas mudanças importantes de posicionamentos filosóficos, permite diversas entradas ou abordagens de seu pensamento. Sua filosofia moral madura se encontra desenvolvida em After Virtue ([1981] 2007), Whose Justice? Which Rationality? (1989) e Three Rival Versions of Moral Enquiry (1991), obras que o proprio Macintyre reconhece como formando um projeto teórico uniforme. Esses livros são obras mais sistemáticas, nas quais MacIntyre estabelece suas posições proporcionando uma leitura estável de sua argumentação, a despeito de algumas modificações que natuiralimente ocorrem em sua formulação teórica entre a publicação de uma obra e outra, uma vez que é um pensamento vivo, rigorosamente em andamento. Mais recentemente acrescentou-se o Dependent Rational Animals (1999), que se mantém na linha de reflexão estabelecida pela tríade anterior, embora aprofundando alguns pontos mais específicos, especialmente na direção do desenvolvimento de uma teoria das virtudes, e que podemos chamar de sua "antropologia filosófica", no qual buscou recuperar em outros termos a biologia metafísica de Aristóteles que ele havia anteriormente descartada em After Virtue; e ainda Edith Stein. A Philosophical Prologue 1913-1922 (2006), onde busca demonstrar como a filosofia pode formar uma pessoa e não simplesmente ser uma formação acadêmica em abstrato - Macintyre mantém essa perspectiva da constituição de uma tradição de pesquisa racional também em seu livro de 2009, "God, Philosophy, Universities: A selective history of catholic philosophical tradition". A presença de Tomás de Aquino na filosofia de MacTntyre faz-se como algo importante teoricamente somente a partir de Whose Justice? Which Rationality? (1989) em diante, assumindo uma configuração plena em Three Rival Versions of Moral Enquiry (1991), First Principles, Final Ends and Contemporary Philosophical Issues (1990) e em Dependent Rational Animals (1999). Ver também Carvallho (2013, 2001, 2011b); Rouard (2010).
} 
Tomismo seria mais um estágio no seu desenvolvimento, não cabendo assim também a acusação de que haveria uma interpretação equivocada do pensamento de Tomás de Aquino por parte de MacIntyre. Nesse sentido, essa sua apropriação não poderia, a rigor, estar voltada para caracterizar-se como, ao final das contas, um autor genuinamente tomista, mas, sim, como um representante dessa tradição das virtudes, onde a filosofia tomista estaria eventualmente disponibilizando ferramentas de resolução de problemas que, necessariamente, não precisariam ser as únicas em seu interior.

Desse modo, a chave dessa leitura está, a nosso ver, na meta-teoria macintyriana da racionalidade das tradições, cuja matriz conceitual tem fortes elementos oriundos da hermenêutica filosófica de Hans-Georg Gadamer ${ }^{18}$ e da filosofia da ciência de Thomas Kulhn $n^{19}$, com influência significativa da pragmática do Wittgenstein das Investigações Filosóficas $(1991)^{20}$. O conceito macintyriano de "pesquisa racional constituída pela tradição e dela constitutiva", é o coração de seu edifício teórico no tocante à compreensão da racionalidade ética, tanto prática como teórica, e às relações entre tradição e racionalidade. É na formulação desse conceito que se encontra as maiores evidências do débito de MacIntyre à hermenêutica de Gadamer e ao seu conceito de eficácia histórica; é também através desse conceito que se mostra toda a carga histórica e os componentes narrativos que MacIntyre incorpora em seu conceito de racionalidade enraizada no interior das tradições - como apontam Carvalho (2013) e Bielskis (2005) - bem como seus débitos à contribuição filosófica de matiz pragmático. Além disso, é em torno desse conceito que se constitui o que chamaríamos, seguindo a sugestão de Knight (1999), a meta-teoria macintyriana da racionalidade das tradições, que tem como um complemento a teoria substancial da racionalidade prática, sua teoria das virtudes. Entendemos que é nessa sua meta-teoria da racionalidade das tradições - e aqui discordando radicalmente de Knight - que MacIntyre incorporou os elementos teóricos da hermenêutica gadameriana, o locus teórico onde opera a "pequena hermenêutica", de natureza nãometafísica, anti-fundacionalista, essencial para sua filosofia moral. ${ }^{21}$

Já sua teoria substancial da racionalidade prática (ou sula teoria das virtudes) é, agora aqui estamos concordando com Knight (1999), fundamentalmente aristotélicotomista, especialmente em suas últimas formulações em Three Rival Versions of Moral Enquiry e Dependent Rational Animals, bem como nas obras que as seguiram. Mas, e aqui reside nossa chave interpretativa, essa apropriação da filosofia de Tomás de Aquino por MacIntyre no âmbito de sua teoria substancial da racionalidade prática pressupõe sua meta-teoria da racionalidade das tradições, cuja formulação teórica é de matriz hermenêutico-pragmática e, por conseguinte, não tomista. Essa meta-teoria da racionalidade das tradições de matiz hermenêutico-pragmático deve, a nosso ver, ser o pressuposto necessário para se compreender adequadamente a apropriação teórica que MacIntyre tem feito do pensamento de Tomás de Aquino, ao situá-lo no interior de uma tradição moral de pesquisa racional que vem desde Aristóteles refletindo sobre a ação lhumana a partir do lugar necessário das virtudes na sua constituição moral. ${ }^{22}$

Contudo, essa linha interpretativa precisa ser complexificada para alcançar a teoria ou concepção de verdade que está operando na meta-teoria da racionalidade das tradições, de modo a dar conta do universo filosófico que MacIntyre está enfrentando como observou bem Rouard (2010), MacIntyre não tem uma teoria da verdade, mas opera com uma concepção construída ao longo de sua trajetória intelectual. Há uma tensão entre a posição anti-fundacionalista que MacIntyre sustenta contra o Iluminismo, ao apresentar o que julga ser o fracasso deste em fundamentar racionalmente a ética pelo abandono da teleologia aristotélica, mas ao mesmo tempo combatendo a sequela relativista deste

${ }^{18}$ Ver Carvalho (2013) e Bielskis (2005)

${ }^{19}$ Ver Carvalho (1999).

${ }^{20}$ Ver Hauerwas (2007) e Macintyre (2006). Sobre a verdade em Wittgenstein, ver Simões (2008). Essa conexão de Macintyre com Wittgenstein mereceria, a nosso ver, um estudo mais sistemático.

${ }^{21}$ Aqui, de certo modo, nos confrontamos com Reames (1998); ver também Carvalho (2013).

22 Sobre a compreensão de Macintyre da filosofia de Tomás como afirmando uma tradição filosófico-moralteológica, e do Tomismo como submetido a um debate intemo crucial, ver Cariño (2016). 
mesmo Iluminismo, assumindo, assim, uma perspectiva anti-relativista, esquecendo-se de que a posição relativista é, talvez, resultante necessária desse mesmo antifundacionalismo que ele, MacIntyre, defendera em Depois da Virtude. Como lembra Trifiró (2006), MacIntyre tentou encontrar um "equilibrio entre anti-fundacionalismo e anti-relativismo, sem perceber que o relativismo que ele tem em mente não é aquele relativismo corrosivo de 'qualquer coisa vale' contra o qual Rorty e Putnam argumentam" $(\mathrm{p} .141){ }^{23}$

Isso significa dizer que há problemas sérios de tensão entre a concepção de racionalidade que MacIntyre formulou para sustentar sua teleologia não-metafísica, presente em Depois da Virtude e em Justiça de Quem? Qual Racionalidade?, e suas obras posteriores, que trazem de volta uma metafísica de base tomista. Essa base antifundacionalista em MacIntyre é reafirmada em sua teoria da racionalidade das tradições como sendo um torpedo destruidor do liberalismo, mas paradoxalmente acaba reafirmando o princípio da razoabilidade liberal, anti-fundacionalista, ainda que ele não o diga ou não o reconheça deste modo. E com o giro tomista tomado firmemente a partir de Three Rival Versions of Moral Enquiry, consolidado nas demais obras em diante, MacIntyre parece não perceber a radicalidade dessa tensão, na medida em que a base metafísica e teológica presente em Tomás de Aquino aparentemente não é vista por ele como problemática para o conteúdo anti-fundacionalista inicialmente incorporado justamente o que há de significantemente contemporâneo na sua meta-teoria da racionalidade das tradições e onde mais reside sua originalidade filosófica.

Sua meta-teoria da racionalidade das tradições, ao ser pensada apenas como abrigada nas bases aristotélico-tomistas, acaba gerando tensão entre sua matriz originalmente anti-fundacionalista e os temas metafísicos do Tomismo. Como lembra Haldane (1994), MacIntyre pouco traballha temas metafísicos tomistas em sua trilogia After Virtue, Whose justice? Which rationality? e Three Rival Versions of Moral Enquiry. Segundo Haldane, para que MacIntyre possa sustentar de vez seu "tomismo" haveria de escrever algo mais, mesmo uma outra obra cuja temática seria The truth of Thomism ou mais geralmente The requirements of truth (p.92). Rouard (2011) informa que o próprio MacIntyre afirmara estar traballhando em uma obra cujo objeto seria o problema da verdade, entretanto ele abandonou esse projeto e se dedicou à discussão sobre as virtudes e sobre a lei natural. ${ }^{24}$

O problema aqui é porque MacIntyre oscila na sua obra entre algumas vezes falar da verdade em termos metafísicos imutáveis, na direção do realismo metafísico tomista, mas em outras vezes fala da verdade em termos muito próximos do pragmatismo, num formato antirrealista, especialmente em suas apropriações de conceitos da filosofia da ciência de Kuhn e de alguns elementos da filosofia da linguagem do Wittgenstein das Investigações Filosóficas, bem como em sua apropriação da crítica marxiana ao capitalismo e ao liberalismo econômico e político, ao focar na história das tradições como lugar de confirmação ou negação da verdade. O conceito de tradiç̧ão de pesquisa racional em MacIntyre não estaria, assim, a nosso ver, necessariamente próximo à epistemologia e à metafísica tomistas, solapando sua pretensão de uma ética das virtudes de base exclusivamente aristotélico-tomista.

Coleman (1994) levanta também questionamento importante a respeito dessa fidelidade da meta-teoria macintyreana da racionalidade das tradições ao Tomismo. 0 ponto central reside no fato de a teleologia da teoria das virtudes em Tomás de Aquino ser metafísica, isto é, com pretensão de ser fixa e natural, conduzindo a um telos divino, supranatural; já a teoria das virtudes formulada no contexto de uma meta-teoria da racionalidade das tradições em MacIntyre não o é, tem matizes historicizados e

${ }^{23}$ Assim, MacIntyre poderia estar compartillhando, em sua concepção da racionalidade das tradições morais, de elementos pragmatistas, presentes em Rorty e Putnam, cuja origem final estaria, a nosso ver, na pragmática wittgensteiniana. Mas esse não será o nosso foco aqui no traballo, dado o tamanho do texto e a investigação exigida para isso.

${ }^{24}$ Solbre Macintyre a lei natural, ver Gonçalves (2018) 
convencionalistas em suas origens. ${ }^{25}$ Tal incompatibilidade entre as duas perspectivas põe em dúvida justamente a pretensão de MacIntyre de estar conseguindo fazer uma fusão de horizontes, usando aqui a terminologia da hermenêutica de Gadamer, entre sua concepção não-metafísica da racionalidade das tradições com as teorias das virtudes de Aristóteles e de Tomás de Aquino, que possuem bases claramente metafísicas e a última ainda fortemente teológica. ${ }^{26}$

Em suma, aquela nossa tese inicial de que a apropriação de Tomás de Aquino por MacIntyre deveria tomar como ponto de entrada central sua meta-teoria da racionalidade das tradições precisa ser repensada a partir de uma diferenciação: uma coisa é MacIntyre considerar sua meta-teoria da racionalidade das tradições como não tensionada com a teoria das virtudes de base aristotélico-tomista, portanto, querer afirmar a validade de elementos tomistas em detrimento mesmo do enquadramento teórico originário antifundacionalista e antirrealista de sua concepção das tradições de pesquisa racional; outra é a validade de sula meta-teoria da racionalidade das tradições, independentemente considerada, sem levar em conta os elementos tomistas de suas crenças filosóficas, mas pensada agora como não tendo uma articulação necessária numa teoria das virtudes metafisicamente modulada, e focada mais fortemente em suas bases hermenêuticas e pragmáticas.

Noutras palavras, a meta-teoria da racionalidade das tradições proposta por MacIntyre possui, a nosso ver, valor teórico sem depender necessariamente dos elementos tomistas por ele considerados. Nesse sentido, estamos com MacIntyre, mas também contra ele: MacIntyre oscila entre sua defesa da meta-teoria da racionalidade das tradições, de matriz originalmente hermenêutico-pragmática, e sua posição mais substancial, do ponto de vista ético, em torno da perspectiva tomista, na qual está presente um realismo naturalista de matriz supranatural. As tensões geradas entre essas camadas teóricas de sua filosofia são resultantes de uma certa indecisão de MacIntyre em afirmar qual delas teria precedência. A base epistemológica anti-fundacionalista e antirrealista, não metafísica, de sua meta-teoria da racionalidade das tradições entra em choque com os elementos metafísico-teológicos quando buscas formular sua teoria das virtudes a partir do enquadramento tomista. A não-resolução dessa tensão abre a filosofia moral de MacIntyre a muitas críticas e precisa ser equacionada de alguma forma.

o que nos parece aqui, ao contrário, é que sua meta-teoria da racionalidade das tradições precisa ser protegida exatamente desses elementos fundacionalistas supranaturais, teológicos e realistas metafísicos oriundos do Tomismo, de modo a conseguir oferecer uma alternativa à crise moral que ele próprio radicalmente diagnosticou seguindo os passos de Nietzsche, mas sem querer cair no relativismo reconhecendo corretamente a dimensão da relatividade cultural produzida pela finitude humana, mas sem adotar o relativismo moral. Com isso, a perspectiva de MacIntyre pode caminhar claramente em bases hermenêutico-pragmáticas, afirmando uma certa concepção de verdade de cunho historicista, falibilista e narrativista, de modo a poder retirar as tensões aqui elencadas em sua reflexão.

III

A relação com Tomás de Aquino é muito importante para a teorização mais recente de MacIntyre ${ }^{27}$, mas um foco maior no próprio desenvolvimento teórico de MacIntyre explicitará a complexidade do lugar da meta-teoria da racionalidade das tradições - que

${ }^{25}$ Essa tese de um particularismo e convencionalismo em Macintyre é radicalizada por George (1989).

${ }^{26} \mathrm{Em}$ DRA, Macintyre buscou ampliar essa base teórica recorrendo a elementos naturalistas, inclusive com a admissão do evolucionismo de Darwin em sua reflexão. Toner (2008), por exemplo, interpreta o aristotelismo de Macintyre como uma forma de naturalismo e considera a mais bem-sucedida como exemplo do que seria una teoria aristotélica naturalista - sobre isso, ver Sousa (2016). Contrariamente a essa interpretação naturalista em Macintyre, ver Morais (2017).

${ }^{27}$ A direção de uma pesquisa sobre Tomás de Aquino e Macintyre caminharia por autores tomistas como Pieper (1957, 1991), Prouvost (1996), Pinckaers (2005, 2003), Chenu (2005), Torrell (2005, 1999), Cessario (2003, 2004), McCool (2003, 2002, 1999), Gilson (1939, 1999, 2009), Van Steenberghen (1983), Bradley (1997) e Wippel (1989, 1990), dentre outros, num confronto com a interpretação macintyriana do tomismo. Ver também a bibliografia citada em Leonardi, op. cit. 2015. 
incorpora uma concepção de verdade - nas relações arquitetônicas com sua teoria das virtudes. $\mathrm{O}$ anti-fundacionalismo presente na meta-teoria da racionalidade das tradições, que sabemos ser inspirado na matriz gadameriana de sua formulação, ${ }^{28}$ com forte acento pragmático kulhniano e algumas pitadas wittgensteinianas, ${ }^{29}$ produz tensões sérias com os pressupostos metafísicos que MacIntyre incorpora em sula teoria a partir da ótica tomista adotada de 1990 em diante.

A adoção do tomismo exige uma retomada significante da metafísica constitutiva deste, o que seguramente entra em choque, talvez insolúvel, com os elementos historicizantes oriundos da herança hermenêutica e que são componentes essenciais da arquitetura conceitual de sua concepção da racionalidade das tradições. Grande parte do sucesso e impacto inicial da proposta teórica iniciada em After Virtue foi justamente o abandono dessa matriz metafísica em prol de uma perspectiva mais pragmática e sociológica na formulação de sua meta-teoria das tradições morais de pesquisa de pesquisa racional. MacIntyre afirma continuar sustentando sua meta-teoria da racionalidade das tradições, mesmo nas obras onde ele realizou o giro tomista (MacIntyre, 1988, 1990, 1990a, 1999) - ver o novo prefácio à 3a edição de After Virtue (2007).

Embora Lutz (2004) defenda que MacIntyre tem respostas razoáveis a esse tipo de problema, a sustentabilidade do seu projeto filosófico, no tocante a essa tensão entre as camadas teóricas de sua filosofia moral, precisa ser resolvida a partir do abandono daquilo que MacIntyre acredita estar mantendo em sua teoria das virtudes. Sua teoria das virtudes não precisa ser formulada de fuma base denegadora do anti-fundacionalismo, dos elementos hermenêutico-pragmáticos de sua meta-teoria da racionalidade das tradições, em função dos elementos metafísico-teológicos tomistas. Sua meta-teoria da racionalidade das tradições precisa ser radicalizada de modo a que emerja uma concepção da verdade compatível como os elementos historicistas que MacIntyre tanto preza em sua consideração filosófica do agir humano e que, com isso, consiga incorporar sua teoria das virtudes sem tantas tensões teóricas.

O recurso a Tomás de Aquino, por exemplo, em Dependent Rational Animal (1999), buscando ancorar à ética das virtudes o reconhecimento da identidade animal do ser humano juntamente com a vulnerabilidade e aflição às quais está submetido, se faz compreendendo o ser humano a partir de uma identidade animal - mas essa animalidade do humano é justamente uma lherança aristotélica, não tomasiana; já a vulnerabilidade e as aflições são temas tomasianos. MacIntyre entende que os seres humanos enfrentam uma grande quantidade de aflições e uma grande maioria padece em algum momento de sua vida de alguma enfermidade proveniente de tal dimensão animal, mas a forma como cada um enfrenta tais problemas depende em grande parte dos outros para sua sobrevivência.

Dessa forma, MacIntyre nessa obra voltou-se para o que foi em grande parte esquecida pela filosofia moral ocidental: o reconhecimento das aflições a que os seres humanos são vullneráveis, bem como os laços de dependência que são necessários para a manutenção de uma vida em comum. Assim, salienta a importância que tem o cultivo das virtudes para que o ser humano possa se desenvolver a partir de sua condição animal até chegar a ser um agente racional e independente, pois apenas por meio das virtudes podese reconhecer a dependência e as incapacidades humanas. É é aqui que reside o problema: se pensar as virtudes a partir dessa matriz biológica significar a retomada disfarçada de uma perspectiva metafísico-teológica, mesmo que biologicamente modulada, MacIntyre porá em risco sua meta-teoria da racionalidade das tradições, reafirmando o fundacionalismo metafísico que tanto criticara originariamente.

\footnotetext{
${ }^{28}$ Além de sofrer também de maiores dificuldades do que aquelas que o círculo hermenêutico formulado por Gadamer encontra no enfrentamento da racionalidade universalista oriunda do Tluminismo. Sobre isso, ver Tates (1998).

${ }^{29}$ Sobre isso, ver, por exemplo, a avaliação de Hauerwas (2007): "the center of MacIntyre's work was his development of key arguments from Witgenstein concerning the conditions necessary for our actions to be intelligible to others as well as ourselves". Ver também Macintyre (2002).
} 
O que se faz necessário é garantir que essa abordagem das virtudes em MacIntyre não signifique necessariamente a retomada das bases metafísico-teológicas, fundacionalistas, que foram recusadas em sua meta-teoria da racionalidade das tradições. As virtudes, pelo seu caráter social e visceral vínculo com as práticas, nos remetem às bases pragmáticas, não metafísicas, anti-fundacionalistas presentes em sula concepção da racionalidade das tradições. Isso significa que o recurso a Tomás de Aquino deva ser pensado não como um fim, mas como um meio para a afirmação de uma teoria falibilista; não relativista, anti-fundacionalista, mas não desprovida de regras objetivas, de verdade. ${ }^{30}$ Cabe aos pósteros de MacIntyre desenvolverem tal teoria, de modo a sustentar a integração das camadas centrais da filosofia moral macintyriana. Um grande veio de discussão e pesquisa, dessa maneira, que se abre diante do estudo de MacIntyre, é, a nosso ver, essa busca de uma teoria da verdade hermenêutico-pragmática pressuposta pela teoria das virtudes e pela meta-teoria da racionalidade das tradições presentes em sua obra - mesmo contrariamente aos seus posicionamentos mais recentes, como os veremos logo a seguir.

MacIntyre tematizou mais estritamente a questão da verdade em dois ensaios, "Philosophy recalled to its tasks: a Thomistic Reading of Fides et Ratio" e "Truth as a good: a reflection on Fides et Ratio" - republicados em seu Collected Papers, Vol. 1 (2006) -, nos quais promove a assunção do realismo metafísico-teológico de Tomás de Aquino. Ali remete-se à discussão sobre a verdade na filosofia analítica recente, segundo ele, centrada quase exclusivamente em questões semânticas como sendo anteriores e independentes de qualquer questão metafísica. Tais perspectivas pecariam por operarem uma noção de verdade de uso restrito, como se "É verdadeiro" e "É falso" fossem predicados apenas de sentenças proferidas, a ponto de concluírem de que tais predicados seriam redundantes e poderiam ser eliminadas da linguagem sem qualquer perda - a visão eliminativista radical.

MacIntyre quer acentuar a amplitude da teoria tomasiana da verdade como correspondência entre intelecto/mente e coisa, apontando a verdade não apenas como uma propriedade de proposições asseridas sobre um objeto particular, mas também da própria mente ou intelecto e igualmente das coisas. No primeiro ensaio, a partir das Questiones Disputatae de Veritate, de Tomás de Aquino, enfatiza três características dessa teoria: Primeiro, entre os diversos usos de "é verdadeiro" e "é falso", o uso primário é aquele segundo o qual verdade é o

predicado de uma relação entre o intelecto e aquelas realidades que o intelecto encontra e sobre as quais julga teórica e praticamente. A essas realidades o intelecto pode ser mais ou menos adequado. É adequado quando seus juízos e concepções de como são as coisas são idênticos a como as coisas de fato são (I, i; [...] "Verdade é a adequação de coisa e intelecto" [...]). (MacIntyre, 2006, p.185)

Segundo, a verdade envolve uma compreensão e, mais que isso, entender essa compreensão como um objetivo último do intelecto, que se põe como um fim em si mesmo de sua atividade. O movimento próprio do intelecto é da inadequação para a adequação, a partir da medida externa e independente dele provida pelas coisas que são objetos de seu entendimento e compreensão. $E$ as próprias coisas também são portadoras dessa propriedade. "Verdade é, assim, primariamente uma propriedade do intelecto ( $I, 2)$, contudo as coisas que proveem ao intelecto com a medida de sua adequação podem elas mesmas também ser ditas verdadeiras ou falsas" (id., p.185-6).

Terceiro, MacIntyre acentua os compromissos metafísicos-teológicos requeridos pela teoria tomasiana para explicar as propriedades semânticas dos predicados de verdade: há uma relação causal entre o intelecto ou mente de um indivíduo humano que julga, as coisas relevantes para o juízo e, por fim, o intelecto divino. Uma coisa é dita verdadeira ou falsa se ela se adequa a um intelecto, por causar um juízo verdadeiro de si

${ }^{30}$ Sobre o problema do relativismo em MacIntyre, ver Mosteller (2008a, 2008b). 
neste, e, por sua vez, se adequa ao intelecto divino na medida em que cumpre aquilo que este determina na ordem das coisas. "E a caracterização desse objeto para o propósito de tal explicação [da verdade de um juízo] nos referirá às propriedades das coisas que tais coisas possuem como partes do ordenamento divino do universo" (ibid., p.186). Nesse sentido, a ideia de que há uma ordem das coisas que existe independente de qualquer apreensão por alguma mente ou intelecto particular é um pressuposto de nossos juízos de verdade e falsidade, bem como de nossas atividades em busca da compreensão adequada de como as coisas são.

Mas esse intelecto ou mente que se conecta numa relação de causalidade com seus objetos não é um sujeito epistêmico transcendental, abstraído de suas relações de particularidade com o mundo. A compreensão que a mente, por exemplo, tem de si mesma é obtida através do exercício de seus poderes e virtudes intelectuais em um processo de busca de uma compreensão cada vez mais adequada de seus objetos particulares, corrigindo seus juízos à luz das novas evidências - não é um exercício introspectivo, de auto-escrutínio interno. Aqui vige a compreensão tomasiana de progresso intelectual que se diferencia daquela do progresso científico, vez que, para este último, se o progresso

consiste exclusivamente no desenvolvimento de teorias mais e mais adequadas, através de um processo de rejeição, revisão e invenção conceitual, para a primeira é uma matéria não somente de aperfeiçoar, desse modo, nossas teorias, nossas ciências, mas também de aperfeiçoamento das mentes dos pesquisadores, dos teóricos. (id., p. 186)

Segundo MacIntyre, essa concepção de verdade pressupõe um falseacionismo como sua contraparte necessária, vez que as asserções podem falhar em relação à verdade. A Suma Teológica seria exemplar disso na medida em que a estrutura interna de seus artigos são testemunhos de que "só através de um reconhecimento do devido peso a todas as dificuldades e objeções é que o progresso intelectual vai ser feito" (ibid., 187). Nossos juízos serão capazes de serem ditos verdadeiros somente porque eles são falsificáveis, ou seja, sujeitos ao veredito das experiências que podem falseá-los, de modo que "eu possa esperar mover-me propositadamente da falsidade para a verdade, na direção de uma relação na qual minha mente é mais adequada a seus objetos do que era anteriormente" (id., p. 188). Nossa capacidade de categorizar e conceituar para tornar inteligível a realidade é dependente da própria inteligibilidade que os objetos de nossa percepção e entendimento tem per se, das propriedades que possuem e os tornam aptos para categorização e conceituação de uma determinada forma e não de outra. Com isso, necessitamos "ser capazes e realmente temos a habilidade de identificar e re-identificar objetos independentemente dessas categorizações e conceitualizações, sejam erradas ou acuradas" (ibid., p. 190).

Aqui MacIntyre acentua a oposição dessa concepção realista frente às teses centrais do pragmatismo e nominalismo contemporâneos, que recusam, em suas diferentes versões, a inter-relação tomista entre verdade, inteligibilididade e uma ordem das coisas independente da mente humana na forma de tipos naturais ou naturezas essenciais dos objetos. O caráter teleológico que Aquino atribui ao ordenamento das coisas seria o ponto central dessa recusa pelos pragmatistas e nominalistas, vez que a posição tomista afirma que cada coisa tem um lugar no ordenamento geral, um fim específico a ser cumprido em sua trajetória existencial. "E nossa compreensão desse direcionamento permanece incompleta até que reconheçamos que só pode ser explicada pela referência a Deus como causa primeira e final" (id., p. 191). Essa afirmação da possibilidade de haver uma visão das coisas a partir do olho de Deus, que constitui um ponto focal do realismo metafísico-teológico tomista, é que vai gerar tensões sérias na teorização de MacIntyre que aqui apontamos. Segundo MacIntyre, o realismo tomista seria um pressuposto presente em qualquer teorização do homem comum, daí se seguiria que 
Qualquer tipo de filosofia que pretenda ser capaz de funcionar como a filosofila tem que funcionar, se pretende realizar seus fins próprios, pode ser tomista ou mesmo anti-tomista em muitos aspectos - como eram as filosofilas de Scotus, Pascal e Newman, como são as filosofias das tradições fenomenológica e Ortodoxa oriental - mas que terão que encontrar alguim lugar para aquelas verdades que foram classicamente articuladas como a doutrina do realismo tomista (Ibid., p.192).

Esse realismo tomasiano é reafirmado por MacIntyre no segundo ensaio, "Truth as a good: a reflection on Fides et Ratio" (2006), quando se põe a perguntar sobre o que os filósofos devem esperar de uma teoria da verdade e o que ela nos permitiria compreender. Pare ele, três condições deveriam ser atendidas em uma teoria da verdade apropriada:

Primeiro, deve explicar uma variedade de diferentes usos de "verdadeiro" e "falso", além de outras expressões relacionadas, distinguindo usos primáirios daqueles que são secundários e derivativos. Segundo, necessita explicar por que não podemos deixar de considerar verdade como uim bem, de tal forma que "falso", se predicado de uma crença, um juízo, um testemunho ou uma moeda, ou um amigo, sempre tem a força gerundiva [imperativa] de "İsto é algo a ser rejeitado". $\overline{\mathbb{E}}$ terceiro, entre os usos de "verdadeiro" e seus cognatos que exigem particular atenção a respeito dessa força gerundiva [ỉmperativa] estão expressões como "a verdade sobre tal e tal" ou mais simplesmente "a verdade". (Id o, p. 198)

Na sequência do ensaio, MacIntyre reafirma a tese de que o realismo de Aquino cumpre tais condições - mesmo que pareça estar propondo uma concepção de verdade que não contenha todos os elementos da concepção tomasiana e coloque sua proposta como uma tentativa ou programa de pesquisa e não algo já formulado integralmente - e ainda realiza alguns detalhamentos no tocante à situação da mente na relação com a verdade no contexto de sua meta-teoria da racionalidade das tradições. O calcanhar de Aquiles das teorias da verdade como correspondência é a dificuldade em localizar essa correspondência entre um dado linguístico, as proposições linguísticas que expressam crenças, e a realidade não linguística das coisas, vez que após a virada linguística na filosofia contemporânea é cada vez mais oneroso pensar, conceituar, compreender ou qualquer outra operação intelectual se realizar fora do contexto linguístico - a linguagem é o medium da compreensão, do espírito e esta tem uma historicidade. Como ele mesmo reconhecera anteriormente,

Podemos efetivamente, dizer sobre uim juízo falso que as coisas não são como os juízos declaram ser, ou sobre um juízo verdadeiro que a pessoa que o profere diz que o-que-é é e o-que-não-é não é. Mas não há doìs itens que podem ser distinguidos, um juízo, por um lado, e aquilo que é retratado no juízo, por outro lado, entre os quais uma relação de correspondência existe ou não. (Macintyre, 2001, p. 384)

MacIntyre, então, desloca o foco da correspondência asserção-mundo para a relação mente-mundo, mas, como dissemos antes, essa mente não é concebida como transcendental ou abstraída do mundo, mas nele mergulhado pela sua historicidade e finitude. Sua meta-teoria da racionalidade das tradições supõe exatamente uma mente ou intelecto situada histórica e materialmente em uma sociedade concreta, compartilhando uma cultura, práticas comunitárias, valores e referenciais normativos guiadores para a vida boa. Entretanto, o esforço teórico de MacIntyre nesses ensaios recentes ao pensar essa relação mente-mundo termina por ser formulado em bases obscuras, vez que pressupõe uma relação causal entre nossa mente e as realidades externas a ele, na qual nossos pensamentos são determinados a ser o que são pelo fato de essas realidades serem o que são, sem também esclarecer como essa relação de adequação mente-mundo se estabelece, deixando transparecer ser mais um pressuposto metafísico afirmado do que propriamente uma explicação dessa relação. 
Afirma que sentenças não são portadoras de verdade, mas somente "sentenças proferidas, sentenças usadas por um falante particular para fazer uma asserção particular numa ocasião particular" (MacIntyre, 2006, p. 200). Tais sentenças expressam um juízo emitido a partir do exercício, pelo falante, de seus poderes de discriminação e reconhecimento perceptivos, que fazem com haja uma identidade de conteúdo entre um pensamento particular e como as coisas são de fato. Esses objetos com os quais estabelecemos relações não linguísticas anteriores aos atos de fala e da emissão de juízos sobre eles, nós interagimos com eles, os identificamos e os reconhecemos, sobre os quais cometemos erros e também nos corrigimos; são realidades causalmente eficazes, independentes de nosso querer, responsivos à nossa experiência, que, assim, propiciam a possibilidade de correção dos nossos muito frequentes juízos falsos e, por conseguinte, a adequação ou não de nossas mentes. MacIntyre usa como suporte dessa concepção da independência da verdade em relação ao nosso pensamento uma citação de C. S. Peirce:

Aquilo que é tal que algo verdadeiro sobre ele(a) é ou verdadeiro independentemente do pensamento de qualquer mente ou mentes definidas, ou é pelo menos verdadeiro independentemente do que qualquer pessoa ou grupo individual de pessoas definido pensem sobre essa verdade, é reall (Peirce, C. S. Apud MacIntyre, 2006, p.202).

Como observou Damasceno (2010), "os elementos envolvidos na teoria da verdade como correspondência proposta por MacIntyre são [três]: sujeitos particulares participantes de tradições particulares (mente), crenças dos sujeitos acerca de como as coisas são e as "coisas tais como são" (p.81). Nessa tríade é central o papel da mente para a consecução da sua adequação ou correspondência com o mundo, mas não no formato cartesiano, ou seja, MacIntyre compreende a mente como atividade de enfrentamento do mundo natural e social na forma de atividades de identificação, re-identificação, coleta, separação, classificação e nomeação, por meio de ações tais como tocar, prender, apontar, destruir, construir, chamar, responder, dentre outras.

Assim, a mente é adequada aos seus objetos à medida que as expectativas que ela cria, baseadas em tais atividades, não estão sujeitas à frustração e a lembrança na qual se envolve torna-se capaz de voltar e recuperar o que ela anteriormente encontrara, quer os próprios objetos estejam ainda presentes ou não. A mente sendo informada como resultado de seu envolvimento com os objetos é informada por ambas as imagens que são ou não - para os propósitos da mente representações adequadas das formas em cujos termos os objetos são compreendidos e classificados. (Macintyre, 2001, p. 383)

A veracidade das crenças expressas assertivamente é dependente dessa conexão da mente com o mundo, da capacidade desta de atribuir verdade ou falsidade às crenças e juízos a partir do que as coisas são como tais, mas no contexto histórico-narrativo de uma tradição de pesquisa racional particular, ou seja, enquanto um sujeito situado historicamente, conectado a uma realidade social e racional à qual o juízo se refere. Como descreve Damasceno (2010),

Assim a correspondência está relacionada à discrepância radical entre aquelas crenças antigas aceitas no estágio anterior e o mundo tal como os adeptos da tradição o compreendem num estágio posterior. O que determina a falsidade de crenças e julgamento é a falta de correspondência entre o que a mente então julgava e acreditava e a realidade percebida, classificada e compreendida agora. A tradição aproxima-se da verdade à medida que é capaz de superar as crises epistemológicas no decorrer de sua história, quando a rede de crenças que dava suistentação à compreensão do mundo se rompe e se torna questionável - não é mais uma comparação simples da mente com o mundo, mas a comparação das duas compreensões do muindo entre si que a mente formulou no interior de uima tradição (p.82). 
Entretanto, como é que essa mente se adequa ao mundo e às coisas numa relação de verdade, para além da lida imediata com os objetos no contexto experiencial diário dos humanos? Em que isso seria diferente do que afirmaria o pragmatismo em um contexto operacional da relação com o mundo, se situada essa atividade da mente no contexto de uma tradição de pesquisa racional particular? Como sabemos que a mente está adequada ou não com o mundo, se ela parece estar numa posição que se situla para além da sua própria atividade de conceituação e categorização, como que em uma posição privilegiada epistêmicamente que a permitiria corrigir tal atividade? MacIntyre não esclarece sobre os termos dessa conexão metafísica e que alcança bases teológicas na afirmação da possibilidade do ponto de vista do olho de Deus e de uma ordem geral das coisas, em que cada uma delas tem um papel, lugar e natureza específica, quando perspectivada no vocabulário tomista.

É a possibilidade de um tal ponto de vista que torna inteligível a noção de um movimento direcionado de nossas investigações para um fím últîimo. Pois sem essa concepção de tal ponto de vista absoluto, poderíamos bem concluir que não há tal coisa como uim término final para a pesquisa concemente a qualquer objeto particular (MacIntyre, 2006, p. 208).

Como ele mesmo sustentou um pouco antes disso, é, então, "uma pressuposição metafísica desta visão da verdade que há uma ordem das coisas e que esta ordem existe independente da mente humana, assim como os objetos e conjunto de objetos que encontram seu lugar dentro dela" (id, p. 206). Com isso, MacIntyre parece estar abandonando pontos substanciais da matriz hermenêutico-pragmática que emergiu na sua meta-teoria da racionalidade das tradições, a partir dos diálogos com $\mathrm{H}_{\text {. }}$-G. Gadamer, D. Davidson, $\mathbb{K}$. Popper e $\mathbb{T}$. Kuhn, dando uma inflexão metafísica em sua formulação a partir da influência de Tomás de Aquino na sua obra mais recente, em cuja filosofia enxerga um conteúdo mais substantivo para uma adequada teoria da verdade como correspondência.

\section{IV}

MacIntyre efetivamente oscila entre aprofundar a perspectiva historicista hermenêutico-pragmática, falibilista, na sua meta-teoria da racionalidade das tradições em seus textos iniciais e, a partir dos anos 90 , a afirmação de um ponto de vista particular das virtudes, vinculado à tradição aristotélico-tomista, que incorpora pressupostos fundacionalistas metafísicos e teológicos, gerando a tensão teórica que fizemos alusão anteriormente. E, a nosso ver, este é o desafio teórico posto: uma teoria da verdade satisfatória deve caminhar na direção anti-fundacionalista que está contida na sua metateoria da racionalidade das tradiçōes, de modo a evitar as aporias que o mergullho numa teoria da correspondência modulada metafisica e teologicamente, nos termos do vocabulário filosófico do Tomismo, aporta para a ética das virtudes.

Como observou Rouard (2010), MacIntyre sempre tematizou a verdade como horizonte final de suas investigações, a despeito dos diversos elementos teóricos envolvidos na sua trajetória intelectual, que envolve diferentes guinadas filosóficas importantes, indo desde o estudo dos clássicos literários gregos, passando pela fillosofia da ação, filosofia analítica, marxismo, culturas orais da Irlanda, hermenêutica, filosofia da ciência e filosofia da linguagem. Embora não tenha formulado uma teoria da verdade, MacIntyre fornece os elementos iniciais, a partir de sua meta-teoria da racionalidade das tradições, para a contextualização dos componentes de uma teoria hermenêuticopragmática da verdade apropriada a uma ética das virtudes. Esses componentes estão articulados en tomo da finitude e vulnerabilidade da investigação racional humana, submetida a uma validação histórica e experiencial das comunidades históricas que os humanos constituem na sua relação com o mundo e os outros animais, na forma de tradições morais de pesquisa racional. 
A vulnerabilidade que MacIntyre tematiza no contexto da condição animal do homem, como ente finito sujeito às vicissitudes da fragilidade e dos sofrimentos da vida animal - que compartillhamos com os outros animais não racionais - de modo a aportar uma mellhor compreensão da condição moral do homem e de sua necessidade das virtudes para conquistar sua posição de raciocinador prático independente, é estendida também para o âmbito epistêmico. Aqui MacIntyre está buscando, ao final, uma perspectiva não dualista na consideração epistêmica e também ontológica da mente humana em sua relação com o mundo externo e com os outros homens. Daí porque o conhecimento e, por conseguinte, a verdade não ser uma característica apenas linguística, de proposições isoladas da práxis histórica dos homens, mas ser uma conquista coletiva dos homens em comunidade, na investigação social compartilhada sobre o bem humano a partir de suas experiências acumuladas na forma de tradições morais de pesquisa racional ou de investigação científica.

Nesse sentido, é preciso operar com a perspectiva de que a teoria moral de MacIntyre não seria uma defesa final do Tomismo, mas uma tentativa de levar adiante uma tradição moral de pesquisa racional da qual o Tomismo é apenas mais um estágio no seu desenvolvimento, e que caberia desenvolver uma teoria da verdade com a tarefa de compatibilizar adequadamente as tensões teóricas de sua filosofia moral. Com isso, a tensão entre os elementos epistemológicos pragmáticos e hermenêuticos de sua metateoria da racionalidade das tradições e os elementos metafísicos e teológicos oriundos da matriz tomista, só poderá vir a ser resolvida ou reformulada se o elemento hermenêutico provido por Gadamer (2003) e o debate com a tradição pragmatista - que incluem autores como Davidson $(2001 \mathrm{a}, 2001 \mathrm{~b})$, Rorty $(1979,1982,1989)$ e Putnam $(1981,2002)$, que o próprio MacIntyre reconheceu como importantes no amadurecimento de suas posições, ${ }^{31}$ bem com seu forte interesse em algumas partes da filosofia da linguagem wittgensteiniana $^{32}$ - assumir maior importância para uma concepção da verdade que aponte para uma forma de realismo não-metafísico e não-teológico, com doses pragmáticas significantes em seus critérios epistêmicos.

Cabe acentuar aqui que tanto Gadamer como MacIntyre compartilham a ênfase sobre o papel que a tradição e a interpretação ocupam na compreensão humana, a despeito de diferenças entre suas teorias. Daí porque a tese de Gadamer do pertencimento de palavra e realidade, abordado como um componente epistemológico realista requerido para sua hermenêutica filosófica não mergulhar no relativismo ${ }^{33}$ - sobre isso ver Wachterhauser (1994) -, bem como a tese de MacIntyre do pertencimento de teoria e prática na investigação moral, concebida como uma expressão do nexo realista entre lingulagem e mundo, no contexto das práticas sociais e históricas dos homens, são fundamentais para uma concepção de verdade apropriada a uma ética das virtudes. Assim talvez possamos formular a tese provisória de que esses realismos de Gadamer e MacIntyre tem um papel complementar e contribuam para uma melhor compreensão das relações entre linguagem e mundo, especialmente no campo da filosofia prática.

A ideia de um realismo hermenêutico ${ }^{34}$ implica que há uma conexão significativa entre linguagem e mundo. A coisa, a realidade do mundo é o referencial que modula a linguagem e o pensamento. Sem esse pressuposto não faz sentido a linguagem humana, que se tornaria delírio mental puro e simples. A linguagem estabelece verdades sob o signo do tempo, se realiza na finitude e historicidade humanas, seja no pensamento, na práxis social ou na história da ciência. A reflexividade da consciência humana, provida linguisticamente, permite a consciência de suas limitações: é a consciência lhermenêutica da falseabilidade, da parcialidade e da historicidade. É sempre no diálogo racional,

\footnotetext{
${ }^{31}$ Ver Macintyre (2009b).

32 Ver Hauerwas (2007) e Macintyre (2006).

${ }^{33}$ Essa acusação de relativismo é recorrente contra a hermenêutica gadameriana. Para uma discussão mais ampla, ver Schmidt (1995).

${ }^{34}$ Para o realismo hermenêutico heideggeriano, ver os ensaios "Heidegger's Hermeneutic Realism" e "How Heidegger defends the possibility of a correspondence theory of truth with respect to the entities of Natural science", de Dreyfus (2017).
} 
falibilista e aberto com outras tradições que a verdade é buscada, na forma de sistemas de pensamento historicamente situados - nunca como pontos de vistas absolutos - que remetem sempre a algo do e sobre o qual se fala e discute no diálogo linguisticamente mediado.

O caráter vulnerável, finito, histórico e falibilista da investigação racional no âmbito das tradições de pesquisa, que deve também à condição animal do próprio homem, requer uma verdade concebida a partir de uma combinação de elementos do que Kirkham (1995) chamou de os três projetos básicos de se teorizar a verdade: o metafísico, o justificacional e o dos atos de fala. Em MacIntyre, a verdade não poderá ser concebida sem que se possua algum fundo realista, alguma conexão entre linguagem/mente e mundo/realidade, mas, a nosso ver, a partir de uma certa perspectiva realista deflacionada, naturalizada moderadamente, na medida em que só será obtida a partir da atividade humana e suas características biológicas, sociais e históricas. Nenhuma proposição/interpretação do mundo poderá ser concebida se não se fizer a partîr de estruturas justificacionais e semânticas compartilhadas no interior da práxis social e epistêmica, onde a lógica ocupa um papel importante, mas não como o ponto final de qualquer discussão sobre a verdade de sentenças e compreensões de mundo.

A verdade tem também necessariamente uma dimensão pragmática, na medida em que dizer alguma coisa é também fazer algo, levantar pressupostos, comprometer-se a certos requisitos morais, epistêmicos e ontológicos no contexto de jogos de linguagem e práticas socialmente compartilhadas. A verdade é um evento que se dá na correlação de teorias e proferimentos relacionados com as atividades humanas, com as necessidades da vida, acumulando aquelas que mais contribuem para o bem-estar humano e sua autocompreensão satísfatória, na forma de compreensões historicamente construídas como tradições racionais de pesquisa.

Não se trata de algum convencionalismo pragmático, de veio idealista, que os homens realizariam em torno de certos eventos mundanos e humanos, mas dessa relação prática que os homens têm com o mundo e este com eles, seja na forma da natureza, seja na forma social de comunidades históricas e geograficamente situadas. Uma interação pragmática que se faz pela condição vital do ser humano, pela sua animalidade específica como ente pensante e que se eleva acima do puro instinto, mas sem deixar de possuir essa infraestrutura biológica que compartilha com todos os outros entes naturais e na qual permanece ancorado. A narrativa histórica que fazemos de nossas ações e pensamentos, sua exibição como verdadeiros ou falsos no interior das tradições morais, intelectuais e tecnológicas em que vivemos, compartillhando valores e percepções, dores e sofrimentos, alegrias e tristezas, fins e meios, erguendo uma grade compartilhada de critérios de racionalidade e verdade, isso tudo é o ambiente onde a verdade se tematiza originalmente em MacIntyre, numa recusa de dualismo entre corpo e mente, matéria e espírito, pensamento e mundo. As virtudes morais e intelectuais têm um papel essencial nesse contexto por serem a concretização das experiências de ascensão e queda, sucesso e fracasso dos animais racionais em relação com o mundo, a natureza e a si mesmos. ${ }^{35}$ Assim, verdade não é apenas uma propriedade semântica, mas pragmática da relação do homem e o seu bem próprio, mesmo até no âmbito tecnológico. ${ }^{36}$

Enfim, como não tivemos a pretensão de esgotar o problema abordado, mas de trazê-lo à tona para possibilitar a busca de alguma alternativa possível, temos aqui apontados alguns elementos iniciais de uma proposta de pesquisa para uma ética das virtudes que mantenha os pontos centrais da perspectiva original de MacIntyre, ao mesmo tempo que possibilita o avanço no reconhecimento da historicidade e finitude humanas, sem recurso a absolutos teológicos ou de qualquer outra ordem. Esperamos que isso possa desencadear outras discussões e aprofundamentos nessa direção teórica de uma ética das virtudes hermeneuticamente consciente e mediada pragmaticamente pelo reconhecimento da verdade como própria da historicidade humana e do mundo.

${ }_{35}$ Para uma ampliação da teoria das virtudes de Macintyre para o âmbito ecológico, ver Sousa (2017). ${ }^{36}$ Ver Higgs, Light \& Strong (2000). 


\section{Referências}

$\mathrm{ABBA}$, Giuseppe. Felicità, Vita buona e virtù. Saggio di filosofia morale. Roma: Libreria Ateneo Salesiano, 1989.

APEL, K.-O. Transformação da Filosofia 2 Vol. São Paulo, Loyola, 2000.

AQUINO, Tomás de. Suma Teológica. Vol. I, II, III, VIII. São Paulo: Edições Loyola, 20012003.

BAYNES, $\mathbb{K}$. BOHMAN, J./McCARTHY, T. After Philosophy: End or Transformation? Cambridge: MIT Press, 1987.

BIELSKIS, A. Towards a post-modern understanding of political. From genealogy to hermeneutics. Houndmills/New York: Palgrave Macmillan, 2005.

BLACKBURN, S. Verdade: um guia para os perplexos. Rio de Janeiro, Civilização Brasileira, 2006.

BLACKLEDGE, P.\& KNIGHT, $\mathbb{K}$. (Eds). Virtue and politics. Alasdair MacIntyre's Revolutionary Aristotelianism. Notre Dame: University of Notre Dame Press, 2011.

BRUNO, Fernanda. Máquinas de Ver, Modos de Ser. Porto Alegre: Sulina, 2013.

CARSILIL, Rocco. II problema morale in MacIntyre. Bari: Levante, 2000.

Filosofia morale, educazione e política "moderne". Con MacIntre: oltre Il Comunitarismo e il Liberalismo. Bari: Levante, 2007.

CARIÑO, Jovito $\bar{V}$. Re-thinking Catholic Philosophy: MacIntyre and the tension within Thomism. Kritike.Vol. 10, n.2, December (2016): 191-209.

CARVALHO, Helder Buenos Aires de. Hermenêutica e Filosofia Moral em Alasdair MacIntyre. Curitiba, Editora CRV, 2013.

- Tradição e Racionalidade na Filosofia de Alasdair MacIntyre. São Paullo: Editora Unimarco, 1999.

- Alasdair MacIntyre: um kuhniano da filosofia moral? Apontamentos para uma reflexão sobre racionalidade e história na filosofia moral. Cadernos de Ética e Filosofia Política. 3 (2001): 25-52.

Nota bibliográfica: A antropologia dos animais racionais dependentes. Pensando Revista de Filosofia, V. 1, n.1, p. 106-154, $2010 \mathrm{~b}$.

- Responsabilidade como princípio e virtude: uma reflexão sobre o desafio ético da técnica contemporânea a partir das teorias morais de Hans Jonas e Alasdair MacIntyre. In: SANTOS, Robinson dos (ed). Ética para a civilização tecnológica: em diálogo com Hans Jonas. Curitiba: Editora São Camilo, 2011, p.139-163.

\& SOUSA, José Elielton de. Nietzsche ou MacIntyre: duas alternativas à moralidade moderna? Abstracta, Vol. 6, no 2 (2011b): 252-283.

(org.) Tradição, Moralidade e Racionalidade. Em diálogo com Alasdair MacIntyre.

Porto Alegre/Teresina, Editora Fi/EDUFPI, 2017.

COLEMAN, Janet. MacIntyre and Aquinas. In: HORTON, John \& MENDUS, Susan (eds).

After MacIntyre. Critical Perspectives on the work of Alasdair MacIntyre. Notre Dame: University of Notre Dame Press, 1994. p.65-90.

CRISP, R. \& SLOTE, M. (eds). Virtue ethics. Oxford: OUP, 1997.

DAMASCENO, Márcia M. Tradição, razão e verdade na filosofia moral de Alasdair MacIntyre. Fortaleza, CE: PPG Filosofia/UFC, 2010. (Dissertação de Mestrado)

DAVIDSON, Donald. Essays on Actions and Events. 2a ed. Oxford: Clarendon Press, 2001a。

Inquiries into Truth and Interpretation. 2a ed. Oxford: Clarendon Press, $2001 \mathrm{~b}$. 
DARWALL, S. (ed). Virtue ethics. Malden: Blackwell, 2003.

; GIBBARD, A.; RAILTON, P. Metaética. Algumas Tendências. Florianópolis: Editora da UFSC, 2013.

DÍAZ, Francisco Javier de la Torre. El modelo de diálogo intercultural de Alasdair MacIntyre: el diálogo entre las diferentes tradiciones. Madrid: Dykinson, 2001.

DREYFUS, H. L. Background Practices. Essays on the understanding of Being. Editado por Mark A. Wrathall. Oxford: Oxford University Press, 2017.

ENGEL, P. Truth. Chesham, Acumen, 2002.

FAIRWEATHER, A. (ed.). Virtue Epistemology Naturalized: Bridges between Virtue Epistemology and Philosophy of Science. Dordrecht, Springer Publishing, 2014.

\& ZAGZEBSKI, L. T. (eds). Virtue epistemology: Essays on Epistemic Virtue and Responsibility. Oxford, OUP, 2001.

FIGUEIREDO, Lidia. La filosofía narrativa de Alasdair MacIntyre. Pamplona: EUNSA, 1999.

FULLER, Michael. Making Sense of MacIntyre. London: Avebury, 1998.

GANNON, J. F. MacIntyre's Historicism. Cross Currents. XXXIX (1989): 91-96.

GADAMER, Hans-Georg. Truth and Method. 2a ed. Transl. Joel Weinsheimer. London: Continuum Publishing, [1960] 2004.

GEORGE, Robert P. Moral particularism, Thomism, and traditions. Review of Metaphysics. 42 (1989): 593-605.

GILSON, Étienne. Réalisme thomiste et critique de la connaissance. Paris: Vrin, 1939.

. From Aristotle to Darwin: A journey in final causality, species, and evolution. San Francisco: Ignatius Press, 2009.

The unity of Philosophical Experience: The Medieval Experiment. The Cartesian Experiment. The Modern Experiment. San Francisco : Ignatius Press, 1999.

GONÇALVES, Isabel C. H. A lei natural e os fatos do desacordo moral na filosofia moral de Alasdair MacIntyre. In CARVALHO, H. B. A. de (Org.) Tradição, Moralidade e Racionalidade. Em diálogo com Alasdair MacIntyre. Porto Alegre/Teresina, Editora Fi/EDUFPI, 2017a, p. 15-42.

. Lei natural e natureza humana na filosofia moral de Alasdair MacIntyre Curitiba: Editora CRV, 2018.

HALDANE, John. MacIntyre's Thomist revival: what next? In: HORTON, John \& MENDUS, Susan (eds). After MacIntyre. Critical Perspectives on the work of Alasdair MacIntyre. Notre Dame: University of Notre Dame Press, 1994. p.91-107.

HAUERWAS, Stanley. The virtues of Alasdair MacIntyre. First Things, (2007). Acessado no website http://www.firstthings.com/article.php3?id_article=6041 em 7 de março de 2009 .

HIBBS, Thomas S. Alasdair MacIntyre, Tradition, and the Christian Philosopher. The Modern Schoolman. LXVIII (1991): 211-223.

MacIntyre's postmodernism: reflections on Three Rival Versions of Moral Enquiry. The Thomist 57 (1993): 277-297.

HIGGS, E.; LIGHT, A.; STRONG, D. (eds). Technology and the Good Life? Chicago: The University of Chicago Press, 2000.

HOBUSS, João (ed). Ética das Virtudes. Florianópolis, Editora da UFSC, 2001.

HORTON, John \& MENDUS, Susan (eds). After MacIntyre. Critical Perspectives on the work of Alasdair MacIntyre. Notre Dame: University of Notre Dame Press, 1994.

IHDE, D. Philosophy of Technology: An Introduction. New York: Paragon House, 1997. 
JONAS, Hans. The imperative of Responsibility. In search of an Ethics for the technological age. Chicago, The University of Chicago Press, 1984.

KIRIKHAM, R. L. Theories of Truth: A Critical Introduction. Cambridge: MIT Press, 1995.

KNIGHT, Kelvin (Ed). The MacIntyre Reader. Notre Dame: University of Notre Dame Press, 1999.

Aristotelian Philosophy: Ethics and Politics from Aristotle to Macintyre. London: Polity Press, 2007.

LECALDANO, Eugenio. Storia e teoria dell'etica in Alasdair MacIntyre. IN: MARRONE, C: COCCOLI, G.; SANTESE, G.; RATTO, F. (orgs). Specchi Americani. La filosofia europea nel Nuovo Mondo. Roma: Castelvecchi, 1994.

LEONARDI, C. Il teismo di Alasdair MacIntyre a confronto con la teologia post-liberal e post-moderna. Pensando - Revista de Filosofia, V. 6, n.11 (2015): 149-173.

LYNCH, M. The nature of Truth. Cambridge, MA: MIT Press, 2001.

Truth as One and Many. Oxford, OUP, 2009.

LUTZ, Christopher S. Tradition in the ethics of Alasdair MacIntyre. Lanham: Lexington Books, 2004.

MADDALENA, Giovanni. La lotta delle tradizioni: MacIntyre e la filosofia in America Roma: L'Arciere, 2000.

MacINTYRE, A. A Short History of Ethics. New York: MacMillan Publishers Company, 1966.

. After Virtue. A study in moral theory. 2. ed. Notre Dame: University of Notre Dame Press, 1984.

Against the Self-Image of the Age. [1971] 2a ed. Notre Dame: University of Notre Dame Press, 1984b.

Relativism, Power, and Philosophy. After Philosophy: End or Transformation?

Eds. K. Baynes, J. Bohman, T. McCarthy. Cambridge: MIT Press, 1987. pp.385-411.

Whose Justice? Which Rationality? Notre Dame, IN: University of Notre Dame Press, 1988.

. First Principles, Final Ends and Contemporary Philosophical Issues. Milwaukee: Marquette University Press, 1990a.

Three Rival Versions of Moral Enquiry: Encyclopaedia, Genealogy, and Tradition. Notre Dame: University of Notre Dame Press, 1990.

Justiça de Quem? Qual Racionalidade? [1988] Tradução Marcelo Pimenta. 2ª ed.

São Paulo: Loyola, 2001.

Colors, Culture, and Practices. The Wittgenstein legacy. Eds. Peter A. French, Theodore E. Uehling, Jr. Howard $\mathbb{K}$. Wettstein. Notre Dame: University of Notre Dame Press, 1992. pp.1-23.

The Relationship of Philosophy to its Past. IN: RORTY, R.; SCHNEEWIND, J.B.;

SKINNER, Q. (Ed.) Philosophy in History. [1984] 6th ed. Cambridge: Cambridge University Press, 1993. p.31-48.

Dependent Rational Animals: Why Human Beings Need the Virtues. New York: Open Court Publishing Company, 1999.

. Depois da Virtude. Trad. Jussara Simões. Revisão Helder B. A. de Carvalho. Bauru: EDUSC, 2000.

On not having the last word: Thoughts on our debts to Gadamer. IN: MALPAS, Jeff; ARNSWALD, Ulrich; KERSTCHER, Jens (eds). Gadamer's Century: Essays in Honor of Hans-Georg Gadamer. Cambridge: The MIT Press, 2002. pp.157-172.

The tasks of philosophy. Selected Essays, Volume 1. Cambridge: Cambridge University Press, 2006. 
God, Philosophy, Universities. A selective history of catholic philosophical tradition. Lanham, Rowman \& Littlefield Pub, 2009.

Richard Rorty. Common Knowledge. 14, 2 (2009b): 183-192.

MATTEINI, Marina. MacIntyre e la rifondazione dell'etica: la crisi delle ideologie e della morale e il recupero del finalismo etico come bene comune Roma: Cittá Nuova, 1995.

MILLER, Alexander. Introduction to Contemporary Metaethics. London, Wiley Publishing, 2003.

MORAIS, Alexander de A. A concepção de realismo moral anti-naturalista em Alasdair MacIntyre e Charles Taylor. In CARVALHO, Helder B. A. de. (org.) Tradição, Moralidade e Racionalidade. Em diálogo com Alasdair MacIntyre. Porto Alegre/Teresina, Editora Fi/EDUFPI, 2017.

MOSTELLER, T. Relativism: a guide for the perplexed. New York: Continuum, 2008a.

Relativism in Contemporary American Philosophy: MacIntyre, Putnam, and Rorty. New York: Continuum, 2008b.

Theories of Truth: An Introduction. London: Bloomsbury, 2014.

MURPHY, Nancey. Anglo-American Postmodernity: A Response to Clayton and Robbins Zygon. 33, 3 (1998): 475-480.

Postmodern Non-Relativism: Imre Lakatos, Theo Meyering, and Alasdair MacIntyre. Philosophical Forum. 27, 1 (1995): 37-53.

OLIVEIRA, M. A. Reviravolta linguístico-pragmática na filosofia contemporânea. São Paulo, Loyola, 1997.

Ética e Práxis Histórica. São Paulo, Ática, 1995.

PUTNAM, Hilary. The collapse of the fact/value dichotomy, and Other Essays. Cambridge, Harvard University Press, 2002.

Reason, Truth and History. Cambridge, Cambridge University Press, 1981.

RASMUSSEN, David (Ed.) Universalism vs. Communitarianism: Contemporary Debates in Ethics. Cambridge: The MIT Press, 1990.

REAMES, Kent. Metaphysics, history, and moral philosophy: the centrality of the 1990 Aquinas Lecture to MacIntyre's argument for Thomism. The Thomist 62 (1998): 419443.

RORTY, Richard. Philosophy and the Mirror of Nature. Princeton: Princeton University Press, 1979.

Consequences of Pragmatism. Minneapolis: University of Minnesota Press, 1982.

Contingency, Irony, and Solidarity. Cambridge: Cambridge University Press, 1989.

ROUARD, Christophe. La vérité chez Alasdair MacIntyre. Paris, L'Harmattan, 2011.

RUSSELL, D. C. (ed). The Cambridge Companion to Virtue Ethics. Cambridge, CUP, 2013.

SCHATZKI, T. R。; KNORR-CETINA, K。; VON SAVIGNY, E。 (eds). The practice turn in contemporary theory. London, Routledge, 2001.

SCHMIDT, Lawrence $\mathbb{K}$. (ed). The Specter of Relativism. Truth, Dialogue and Phronesis in Philosophical Hermeneutics. Evanston: Northwestern University Press, 1995.

SCHMITT, F. F. (ed). Theories of Truth Malden: Blackwell Pulb, 2004.

SCHROEDER, M. Noncognitivism in Ethics. London, Routledge, 2010.

SIMÕES, Eduardo. Wittgenstein e o problema da verdade. Belo Horizonte: Argumentum, 2008.

SOAMES, S. Understanding Truth. Oxford: OUP, 1999.

SOSA, Ernest. A Virtue Epistemology: Apt Belief and Reflective Knowledge. Volume 1. Oxford, OUP, 2009. 
SOUSA, José Elielton de. As virtudes da responsabilidade compartilhada: uma ampliação da teoria das virtudes de Alasdair MacIntyre Curitiba, Editora CRV, 2017.

SOUSA, José Elielton de. Alasdair MacIntyre e o naturalismo: notas sobre Dependent Rational Animals. In: Lima, Francisco J. G. de; Araújo Neto, Gerson A. de. (Org.). Filosofia Prática, Epistemologia e Hermenêutica. Porto Alegre: Editora Fi, 2016, p. 126-151.

SNOW, N. E. Virtue as social intelligence. London, Routledge, 2010.

STATMAN, D. Virtue Ethics. Georgetown: Georgetown University Press, 1997.

STERBA, James P. The triumph of practice over theory in Ethics. Oxford: OUP, 2005.

TATE, John W. The hermeneutic circle vs. the Enlightenment. Telos. Winter, Issue 110 (1998): p.9-39.

TONER, Christopher. Sorts of naturalism: Requirements for a successful theory. Metaphilosophy, Vol. 39, n. 2, 2008, p.220-250.

TRIFIRÓ, Fabrizio. MacIntyre's tensions: between anti-liberal foundationalism and antifoundationalist liberalism. Etica \& Politica/Ethics \& Politics. VIII, 2006: 127-158.

VAZ, H. C. L. Morte e Vidla da Filosofia. Síntese - Nova Fase. V.18, n.55 (1991):677-691. Ética e Razão Moderna. Síntese-Nova Fase. Vol.22, n.68 (1995): 53-85.

Van HOOFT, S. Understanding Virtue Ethics. Chesham: Acumen Publishing Ltd., 2006.

Van STEENBERGHEN, Fernand. Le Thomisme. Paris: PUF, 1983.

VIEIRA, Daniela Arantes. Alasdair MacIntyre e a Crítica da Modernidade: Uma contribuição para o debate Liberais versus comunitários. Porto Alegre: Sérgio Antonio Fabris Editor, 2002.

WACHTERHAUSER, Brice R. Gadamer's realism. In: Brice R. Wachterhauser (ed.), Hermeneutics and Truth. Evanston: Northwestern University Press, 1994.

Williams, B. Truth and Truthfulness. Cambridge, CUP, 2002.

WITTGENSTEIN, L. Philosophical Investigations: The German Text, with a Revised English Translation $50^{\text {th }}$ Anniversary Commemorative Edition. $3^{\text {a }}$ Ed. Blackwell: Blackwell Publishing, 1991.

ZAGZEBSKI, L. T. Virtues of the Mind: An Inquiry into the nature of virtue and the ethical foundations of knowledge. New York, CUP, 1996.

Doutor em Filosofia (UFMG, 2004)

Professor Associado do Departamento de Filosofia (UFPI)

Professor do PPG Fillosofia (UF'PI)

Professor Colaborador do PPG Filosofia (Doutorado/UFC), Professor Colaborador do PPG Filosofia (UFMA)

E-mail: hbac@ufpi.edu.br 